Do you worry about other psychologists' reactions to your investigations?

I did worry a lot. Everybody likes the fact that whistle-blowers exist, but nobody likes them. People worry about somebody engaging in a witch-hunt, but I have a technique that is accurate, I used it when confronted with evidence, and I subjected it to replication by checking other papers from the same author. That's no more a witch-hunt than a neighbour calling the police when someone breaks into another person's home. I did not take justice into my own hands, I contacted the authorities and they took care of the rest. I suspect some people will be against what I've done, but there is really no personal benefit to someone of doing what I am doing.

\section{So what is your motivation?}

Simply that it is wrong to look the other way. If there's a tool to detect fake data, I'd like people to know about it so we can take findings that aren't true out of our journals. And if it becomes clear that fabrication is not an unusual event, it will be easier for journals to require authors to publish all their raw data. It's extremely hard for fabrication to go undetected if people can look at your data.

A university's reputation suffers a lot when people fake data, but they don't have tools for preventing that - journals do. Journals should be embarrassed when they publish fake data, but there's no stigma. They're portrayed as the victims, but they're more like the facilitators, like a government that looks the other way. I'd like journals to take ownership of the problem and start working towards stopping it.

Previous challenges to data in psychology were made by internal whistle-blowers, but you are not connected to Smeesters. Does that herald an important change?

It's a very important difference. The tool should be broadly applicable to other disciplines. I think it'll be worthwhile to find other ways of finding fake data. We know people are really bad at emulating random data, so there should be all sorts of tests that could be developed.

Is it possible that such methods could falsely ensnare innocent researchers? That's my biggest fear; it's why I look at different papers from the same person. I wouldn't contact anybody unless they had three suspicious papers. And before any concerns become public, a proper investigation should always take place.

\section{INTERVIEW BY ED YONG}

1. Johnson, C. S., Smeesters, D. \& Wheeler, S. C. J. Pers. Soc. Psychol. 102, 32-50 (2012).

2. Smeesters, D. \& Liu, J. J. Exp. Soc. Psychol. 47, 653-656 (2011)

3. Simmons, J. P., Nelson, L. D. \& Simonsohn, U. Psychol. Sci. 22, 1359-1366 (2011).

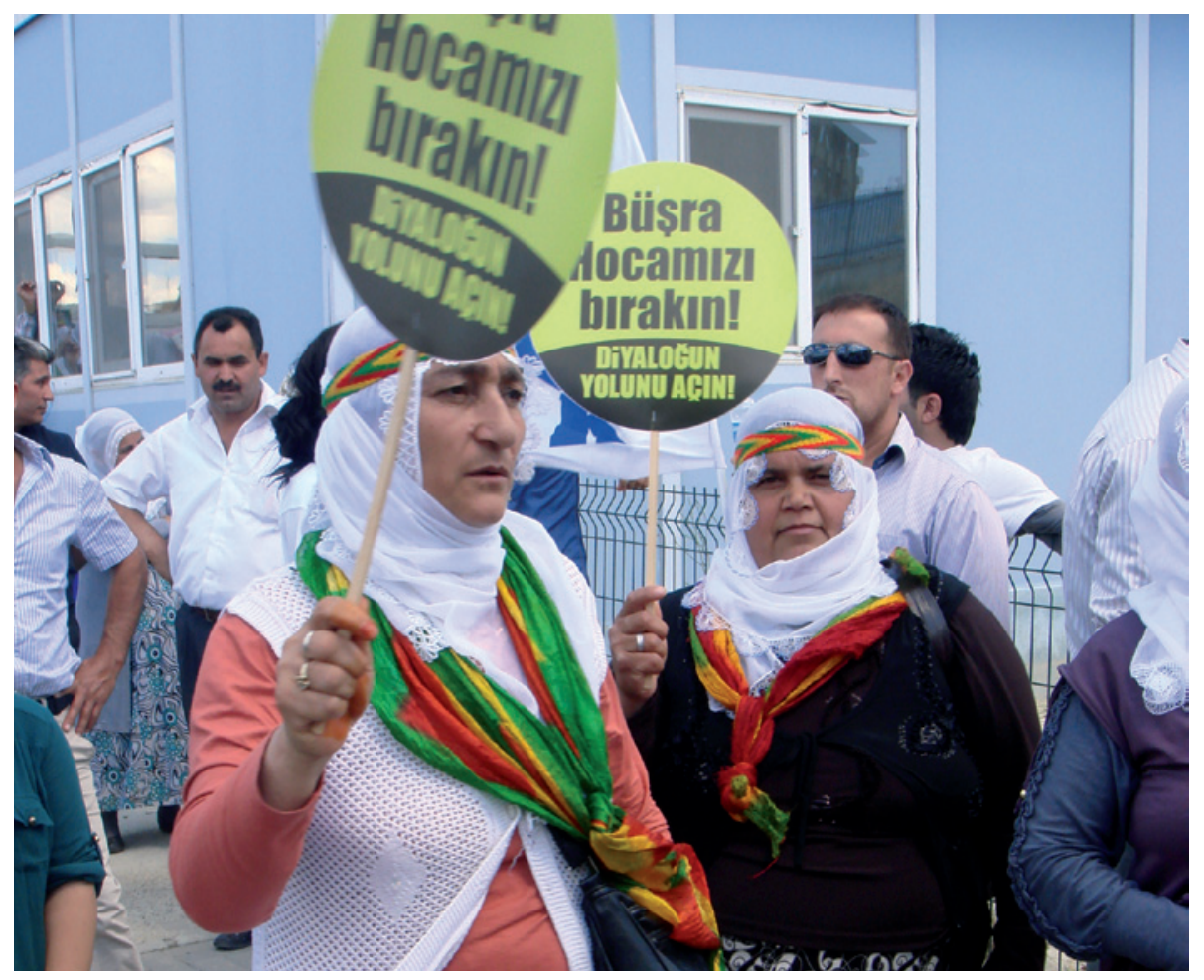

More than 700 people protested at the trial of political scientist Büşra Ersanlı in Istanbul this week.

\title{
HUMAN RIGHTS
}

\section{Turkey cracks down on academic freedom}

\section{External groups hope scrutiny will restrain government.}

\section{BY ALISON ABBOTT}

$\mathrm{T}$ Turkey is upping the pressure on scientists and students who question its policies, and international human-rights advocates are taking notice.

In the past few years, the government has clamped down on the independence of the Scientific and Technological Research Council of Turkey and the Turkish Academy of Sciences (see Nature 477, 131; 2011). It has also harassed and jailed individual academics and students. Now, an international network is launching a campaign to support Turkish scientists whose academic rights it considers to have been violated. The network has issued a report and this week carried out its first concerted street action, when more than 100 of its supporters joined a large protest at the opening of the trial of Büşra Ersanl, a political scientist at Marmara University in Istanbul.

Ersanli was arrested last October, under $\rightarrow$ NATURE.COM For an Editorial on human rights in Turkey, see: go.nature.com/v5jbez
Turkey's 2006 anti-terrorist laws. A member of the legal Peace and Democracy Party, which promotes the rights of Turkey's Kurdish minority, she denies charges of supporting an outlawed separatist terrorist organization, the Kurdish Workers' Party.

Authorities have tried to prevent other scientists from speaking out against industrial interests, says Nesrin Uçarlar, a political scientist who has worked with Ersanlı at Marmara University. One targeted researcher is Onur Hamzaoğlu, an epidemiologist at Kocaeli University in İzmit, who revealed that the region's industrial basin has high pollution levels and increased cancer rates. Hamzaoğlu is now being investigated for unethical behaviour leading to public alarm, and faces a jail sentence.

Ersanlı will be tried alongside 204 others charged with illegally promoting Kurdish rights. Her arrest prompted colleagues in France to launch the International Workgroup on Academic Liberty and Freedom of Research in Turkey (GIT) on 21 November. The group is also drawing attention to the more than 
770 students who are in prison in Turkey, most arrested for protesting against government policies, including the introduction of university fees.

"Freedom of expression in academia is being increasingly clamped down on in Turkey," says Vincent Duclert, a historian at the School for Advanced Studies in the Social Sciences in Paris and a founder of the network. "The GIT initiative will keep the cases in the eye of the international public, and this may bring pressure on Turkish authorities."

Uçarlar, whose PhD thesis on Kurdish language rights was derecognized by Marmara University in 2008, launched GIT's node in Turkey last December. Since then, six further branches have been established in North America and Europe.

GIT Turkey issued a report last week listing a selection of cases of academic rights violations, from arrests on terrorist charges to dismissals for trade-union membership and prosecution for statements deemed harmful to industry. "We don't really know how many cases are out there, because university staff are afraid to speak out," says Uçarlar. "But now we have a platform, people are starting to contact us about their experiences." The group has sent its report to the European Parliament, and has asked that the European Union's annual report on Turkey's bid for membership rates the country on freedom of expression for academics.

Erol Gelenbe, a computer scientist at Imperial College London who was educated in Turkey, points out that although the erosion of academic freedom in the country has accelerated in the past two years, "there has always been little tolerance for independent thinking". He says that at different times over the past few decades, "academics have been expelled from universities either because they were to the right or because they were to the left of the particular government".

Uçarlar agrees that the political situation is "complicated", with right-wingers, left-wingers and staunch secularists all under attack. "I never agreed with the policies of Kemal Gürüz," she says, referring to a former president of the Turkish higher-education council who enforced a ban on wearing the Islamic headscarf in Turkish universities. "But I'm appalled he was arrested on 25 June without credible charges."

Ayşe Erzan, a GIT supporter and a physicist at the Istanbul Technical University who co-founded an alternative science academy when the Turkish Academy of Sciences was put under government management last year, says that "people are getting nervous and there is a feeling we need to resist further slide into undemocratic measures".

\section{Britain names next chief science adviser}

\section{BY EWEN CALLAWAY}

$\mathrm{B}$ iomedical research may soon enjoy an even higher profile in Britain's sciencepolicy agenda. Mark Walport, director of the Wellcome Trust in London, will become the next government chief scientific adviser (GCSA), it was announced last week. He will replace population biologist John Beddington from April 2013.

Walport, a 59-year-old immunologist who took the helm at Wellcome in 2003, will be the first biomedical scientist in 30 years to occupy the role, providing advice directly to Prime Minister David Cameron and the Cabinet. As the outgoing head of one of the world's wealthiest biomedical-research charities, commanding an annual budget of more than $£ 600$ million (US\$940 million), he will be one of the most influential scientists to hold the position.

"I think it's going to be really important in terms of assuring that biomedical science is very high on the agenda in the government," says Nic Jones, chief scientist at the Londonbased charity Cancer Research UK. Although the GCSA does not oversee the research councils that dole out most government science funding, Jones hopes that Walport will make a strong case for biomedical and translational research in the government's next spending review, expected in the next two years.

The UK coalition government has already shown favour for biomedicine over other sciences. It largely protected the Medical Research Council's $£ 800$-million research budget in the latest spending review, and a December 2011 life-sciences strategy which Walport helped to develop - emphasizes translational-research initiatives such as drug repurposing and stem-cell therapies. But Walport will need to be an advocate for science policy-making throughout government, says James Wilsdon, a science-policy expert at the University of Sussex in Brighton, UK. "The key thing will be that he moves above and beyond issues and areas where he's already been associated, to act as a broader leader across the community, across a broader set of issues."

Wilsdon and others expect that, just as Beddington championed government policies to address global food security and climate change, Walport will push his own favoured issues, such

as open access to research literature and data. Last week, the Wellcome Trust announced that it may withhold funding to grant recipients who do not make their research available within six months of publication - a policy instituted under Walport's watch. Open access is already gaining traction in the UK government (see Nature 486, 302-303; 2012), and with Walport beating the same drum, "that creates a real opportunity for more rapid and far-reaching progress to embed these sorts of changes in the research community," says Wilsdon.

One of the key tests for a GCSA is how they deal with crises outside their areas of expertise, says Colin Blakemore, a neuroscientist at the University of Oxford, UK, and former chief executive of the Medical Research Council. Beddington, for example, was confronted with

"The key thing will be that he moves above and beyondissues and areas where he's already been associated." access to expertise to confront such challenges. At the Wellcome Trust, he showed his mettle by pushing through a controversial change to funding policy, targeting more cash to outstanding scientists rather than to individual research projects. He also boosted the trust's commitment to public engagement, the arts and the humanities.

Walport's appointment has unleashed speculation about who will replace him as head of the Wellcome Trust. Insiders say that the hunt for a successor will consider scientists with backgrounds in either academia or industry, and will be explicitly international. "I would expect a global search, a big-hitting shortlist," says Wilsdon. "It is now one of the biggest jobs in international science." - SEE EDITORIALP.5

\section{CORRECTION}

The News story 'Fetal tests spur legal battle' (Nature 486, 454; 2012) located medicalgenomics company Natera in Redwood City, California. The firm has actually relocated to San Carlos, California. 